\title{
PKM Pemanfaatan Limbah Sagu Pada Media Budidaya Jamur Tiram Kelompok Tani Serumpung Sagu Kec. Pekkajoang Kab. Malangke Barat Kab. Luwu
}

\author{
Sitti Maryam Yasin ${ }^{1}$, Rahmi Aziza ${ }^{2}$, dan Mursida ${ }^{3}$ \\ ${ }^{1}$ Email:st.maryamyasin@yahoo.co.id \\ Prodi Agroteknologi, Fakultas Pertanian Unanda \\ 2Email:rahmi.aziza@gmail.com \\ Prodi Agroteknologi, Fakultas Pertanian Unanda \\ ${ }^{3}$ Email:sidaunanda@gmail.com \\ Prodi Manajemen, Fakultas Ekonomi Unanda
}

\begin{abstract}
Abstrak. Malangke Barat adalah kecamatan penghasil sagu terbesar di Luwu Utara yang memiliki luas areal sagu sekitar 1.061 hektar dengan produksi 669 ton tepung sagu. Salah satu desa di Kecamata Malangke Barat yang merupakan sentra pengolahan dan penghasil sagu yaitu Desa Pengkajoang yang mayoritas penduduknya bermata pencaharian sebagai petani sagu. Kelompok Tani serumpung sagu merupakan kelompok tani yang dibentuk oleh masyarakat kampung sagu dan dilegalkan oleh pemerintah Luwu Utara. Permasalahan mitra yaitu, kurangnya pengetahuan tentang inovasi olahan limbah sagu menjadi media budidaya jamur tiram serta belum meiliki peralatan dan bahan budidaya jamur tiram, teknik pengolahan hasil, cara berwirausaha serta sistem-sistem pemasaran. Solusi yang ditawarkan yaitu Penyuluhan dan pelatihan teknologi inovasi olahan limbah menjadi media budidaya jamur tiram serta pengadaan alat dan bahan untuk budidaya jamur tiram, teknik pengolahan hasil jamur tiram, pelatihan pengelolaan manajemen usaha, pelatihan sistem pemasaran bagi wirausaha baru, pelatihan penggunaan media online sebagai media pemasaran bagi mitra dan juga alat pengemasan. Metode yang digunakan dalam pelaksanaan program yaitu metode ceramah, demonstrasi dan pendampingan, serta pembantuan dalam pembuatan website. Luaran dari program ini yaitu produk jamur tiram, olahan jamur tiram dengan desain kemasan, website sebagai media pemasaran online.
\end{abstract}

Kata Kunci; Desa Pekkajoang, limbah sagu, jamur tiram

\section{PENDAHULUAN}

Malangke Barat adalah kecamatan penghasil sagu terbesar di Luwu Utara yang memiliki luas areal sagu sekitar 1.061 hektar dengan produksi 669 ton tepung sagu di tahun 2015. Malangke Barat merupakan salah satu kecamatan yang ada di Kabupaten Luwu Utara yang memiliki luas wilayah $93.75 \mathrm{~km} 2$ yang letaknya berbatasan langsung dengan teluk bone yang mempunyai empat desa yang termasuk daerah hutan sagu. Salah satu desa di Kecamata Malangke Barat yang merupakan sentra pengolahan dan penghasil sagu yaitu Desa Pengkajoang. Masyarakat Desa Pengkajoang ini mayoritas penduduknya bermata pencaharian sebagai petani sagu karena penyebaran sagu di desa ini masih tersedia dalam jumlah yang cukup banyak di bandingkan dari desa lainnya.

To Maega, 2(2), Agustus 2019| 24 
Masyarakat desa ini membentuk lembaga kampung sagu yang bernama kelompok Tani serumpung sagu yang di ketuai oleh "Artin" dimana anggota dari kelompok ini terdiri dari 40 anggota keluarga diantaranya laki-laki dan perempuan. Kelompok tani serumpun sagu didirikan pada tahun 2014 dengan surat keputusan bupati Luwu Utara. Anggota kelompok tani serumpun sagu rata-rata bermata pencaharian sebagai petani sagu. Menurut pemerintah, masyarakat setempat ,melalui hasil wawancara menjelaskan bahwa Desa Pengkajoang merupakan tempat penghasil sagu akan tetapi salah satu masalah yang masih belum dapat terpecahkan yaitu, pengolahan limbah sagu yang belum termanfaatkan.

Peningkatan jumlah produksi sagu berbanding lurus dengan peningkatan jumlah limbah yang dihasilkan. Limbah yang berasal dari pengolahan sagu terbagi menjadi limbah padat, cair, dan gas. Limbah berbentuk padat dan cair belum diolah secara maksimal dan masih menggunakan sistem sederhana yang langsung dialirkan ke dalam sungai yang mengalir di sekitar kawasan sagu. Hal ini dapat menyebabkan pencemaran disekitar sungai. Pada pengolahan sagu terdapat limbah atau hasil ikutan yang berupa kulit batang dan ampas. Ampas yang dihasilkan dari proses ekstraksi ini sekitar 14\% dari total berat basah batang sagu (Flach, 1997). Di sentra-sentra produksi, limbah ampas sagu pada umumnya belum dimanfaatkan dan ditumpuk begitu saja yang pada akhirnya akan mencemari lingkungan (Kompiang, 1995).

Ampas sagu merupakan limbah yang dihasilkan dari pengolahan sagu, dimana dalam proses tersebut diperoleh tepung dan ampas sagu dalam perbandingan $1: 6$, yang kaya akan karbohidrat dan bahan organik lainnya. Ampas yang dihasilkan dari proses extraksi ini sekitar 14\% dari total berat basah batang sagu (Flach, 1997 dan Rumalatu, 1981). Jumlah limbah yang banyak tersebut, sampai saat ini belum dimanfaatkan sebagaimana mestinya hanya dibiarkan menumpuk pada tempat -tempat pengolahan tepung sagu sehingga menyebabkan pencemaran lingkungan.

Ampas sagu yang didapatkan pada proses pengolahan tepung sagu yang disebut sebagai limbah yang terdapat dalam jumlah yang banyak. Menurut masyarakat Desa pengkajoang bahwa limbah yang dihasilkan setelah selesai pengolahan sagu jumlahnya sangat banyak hampir sama dengan hasil tepung sagu yang didapatkan. Limbah sagu yang berbentuk padat hanya dibiarkan begitu saja menumpuk atau dibuang ke sungai atau di rawa-rawa dan dapat mencemari lingkungan. Setelah tiem PKM survei ke lokasi Desa pengkajoang berminat untuk memperdayakan masyarakat melalui kelompok tani serumpun sagu untuk pemanfaatan limbah sagu. Pemanfaatan limbah atau ampas sagu diketahui sangat baik, namun perlu mendapatkan teknologi baru. Teknologi yang kami tawarkan yaitu teknologi ampas sagu menjadi media tumbuh jamur tiram.

Ampas sagu merupakan limbah pengolahan tepung sagu dapat juga dijadikan media tumbuh jamur tiram. Menurut Susanto (2006), ampas sagu banyak tersedia terutama di daerah penghasil sagu. Potensi sagu di Indonesia (1,4juta ha) mencapai lebih dari 50\% potensi pertanian sagu dunia (2,2 juta ha). Salah satu daerah sentra sagu di Sulawesi Selatan adalah Kabupaten Luwu Utara, Kecamatan Malangke Barat dengan produksi 669 ton tepung sagu di tahun 2015. Pengolahan sagu menjadi tepung sagu diperoleh $18,5 \%$ pati sagu dan $81,5 \%$

To Maega, 2(2), Agustus $2019 \mid 25$ 
berupa ampas sagu. Limbah sagu yang terdapat pada sentra produksi sagu di Desa Pekkajoang belum dimanfaatkan dan ditumpuk begitu saja, sehingga dapat mencemari lingkungan. Ampas sagu berpotensi dijadikan media tumbuh jamur tiram karena mengandung residu lignin sebesar $21 \%$, selulosa $20 \%$ dan sisanya merupakan zat ekstraktif dan abu dengan nilai C/N 409 (Kiat 2006).Berdasarkan hasil penelitian yang dilakukan Saputra(2014) pemberian ampas sagu $60 \%$ pada media jamur tiram mempercepat muncul pinhead 14,2 hari dibandingkan tanpa pemberian ampas sagu. Diameter tudung terbaik didapat pada pemberian ampas sagu 30\%, sedangkan diameter tangkai terbaik didapat pada pemberian ampas sagu.

Jamur tiram putih (Pleurotus ostreatusJacq.)merupakan jamur yang banyak dikonsumsi oleh masyarakat sehingga memiliki prospek ekonomi yang baik untuk dikembangkan. Konsumsi masyarakat terhadap jamur tiram putih cukup tinggi dengan asumsi kenaikan pasar sekitar 5\% per tahun, maka pada tahun 2017 kebutuhan jamur tiram untuk wilayah Indonesia akan naik menjadi 22.905 ton per tahun. Kemampuan petani untuk menyediakannya baru sekitar 10.000-12.500 ton per tahun (Piryadi 2013).Menurut data yang disajikan MAJI (Masyarakat Agribisnis Jamur Indonesia), produksi jamur tiram seperti di Jawa Barat 10 ton per hari, di Jakarta 15 ton per hari, dan di Bandung mencapai7-10 ton perhari (Asegab, 2011). Produksi jamur tiram di Provinsi Sulawesi Selatan khususnya Kabupaten Luwu masih sangat sedikit dan belum bisa memenuhi permintaan konsumen dan biasanya hanya didapat dari ibu kota propinsi yaitu Makassar.

Desa Pekkajoang berada dekat dengan teluk Bone yang hanya bermata pencaharian sebagai petani sagu yang memiliki pendapatan rendah dan menyebabkan pemenuhan kebutuhan hidup keluarga kurang tercapai. Dengan pertimbangan demikian sehingga tim PKM merencanakan untuk mengembangkan budidaya jamur tiram dengan menggunakan media limbah sagu di Desa Pekajoang melalui Kelompok Tani Serumpun Sagu. Budidaya jamur tiram merupakan prospek budidaya yang sangat menjanjikan dari segi ekonomi bila dikelola dengan baik, selain itu jamur tiram memiliki kandungan gizi yang baik.

Jamur tiram makanan yang kaya akan gizi tinggi. Kandungan lemak yang rendah menyebabkan jamur tiram layak untuk dikomsumsi. Kandungan nutrisi yang lengkap dan testurnya mirip dengan daging ayam yang merupakan makanan favorit dikalangan masyarakat ekonomi tinggi. Produk jamur tiram dapat dimanfaatkan untuk menambah gizi dan dapat menambah pendapatan pendapatan keluarga. Dari segi bisnis, berbudidaya jamur tiram memiliki perputaran modal yang cepat dengan masa ingkubasi selam 30 hari dan selanjutnya dapat di panen setelah 120 hari. Membuat usaha budidaya jamur tiram sangat menguntungkan. Disamping itu budidaya jamur tiram memiliki kelebihan seperti kemudahan mendapatkan bahan baku, teknologi budidaya yang relatif mudah dipelajari, memiliki resiko gagal yang sangat kecil. Akan tetapi masalah yang dihadapi Kelompok Tani Serumpun sagu yaitu, kurangnya pengetahuan dan keterampilan teknik budidaya jamur tiram, selain itu belum memiliki peralatan dan bahan yang diperlukan untuk budidaya jamur tiram.

Pengolahan hasil jamur tiram apabila sudah menghasilkan produksi yang banyak merupakan masalah bagi petani jamur tiram. Pengolahan hasil menjadi salah satu alternatif untuk mengantisipasi hasil produk yang tidak dapat dipasarkan karena mutu rendah atau tidak

To Maega, 2(2), Agustus 2019| 26 
memenuhi standar maka dapat dimanfaatkan menjadi berbagai macam hasil olahan sehingga dapat meningkatkan nilai tambah dan kelancaran pemasaran. Pengolahan hasil komoditi menjadi berbagai macam produk menjadikan daya simpan yang lebih lama dan jangkauan pemasaran yang luas. Mitra Kelompok Tani Serumpun Sagu mempunyai masalah pengolahan jamur tiram bagi yang tidak masuk standar mutu yang baik atau pemasaran produksi jamur tiram basa melebihi produksi. Pemberdayaan yang dilakukan untuk pemanfaatan limbah sagu di Desa Pekkajoang melalui anggota kelompok tani serumpun padi, selain penerapan bioteknologi pemanfaantan limbah menjadi media tanam jamur tiram dan diharapkan juga dapat mengembangkan agribisnis budidaya jamur tiram yang sebagai komoditi pangan yang bernilai ekonomi tinggi. Sebagaimana kita ketahui bahwa masyarakat di Desa Pekkajoang terdiri dari petani sagu yang berpenghasilan rendah.

\section{METODE PELAKSANAAN}

Metode pelaksanaan kegiatan Pengabdian Kemitraan Masyarakat pada kelompok serumpun sagu dilaksanakan dengan beberapa cara: (1) Sosialisasi (2) Peyuluhan dan (3) Pelatihan dan (4) Pendampingan.

\section{HASIL DAN PEMBAHASAN}

Kegiatan program kemitraan masyarakat yaitu, pemanfaatan limbah sagu menjadi media tumbuh untuk budidaya jamur tiram dilakukan pada daerah hutan sagu atau daerah yang banyak tumbuh tanaman sagu yang terletak pada daerah Kecamatan Pekkajoang Kabupaten Malangke Barat. Kegiatan ini melibatkan Kelompok Tani yang anggotanya mempunyai lahan sagu. Kelompok sagu yang ada di daerah Pekkajoang bernama kelompok sagu Serumpung Sagu. Jumlah masyarakat sasaran yang akan dilibatkan dalam kegiatan ini adalah 20 orang dan diharapkan saling bekerjasama dalam segala hal selama kegiatan berlangsung mulai dari tahap sosialisasi hingga tahap praktek/aplikasi sampai pembuatan produk.

\section{Sosialisasi}

Program PKM ini disosialisasi ke pemerintah, masyarakat di desa Pekkajoang dan ke anggota kelompok tani serumpun sagu yang merupakan mitra. Tim pelaksana telah memperkenalkan program PKM ke masyarakat sasaran (anggota mitra) dan memberikan gambaran tentang kegiatan yang akan dilaksanakan sehingga ia memahami dengan baik sehingga nantinya dapat berperan aktif dalam semua kegiatan. 


\section{To Maega | Jurnal Pengabdian Masyarakat}

P-ISSN: 2622-6332 \& E-ISSN: 2622-6340

TO MAEGA Volume 2 Nomor 2, Agustus 2019, hlm : 24-30

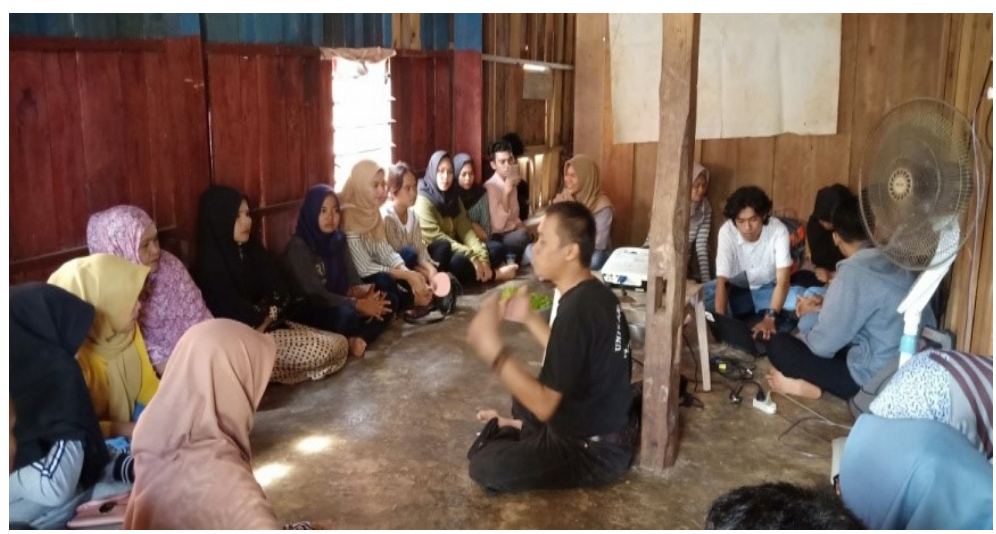

Gambar 1. Sosialisasi Program

2. Pengadaan Alat dan Bahan untuk budidaya jamur tiram

a. Pembuatan kumbung jamur diawali dengan perancangan desain bersama-sama dengan mitra, kemudian dilanjukkan dengan penyediaan bahan dan alat untuk pembuatan kumbung setelah itu diadakan proses pembuatan kumbung secara bersama dengan anggota mitra.



Gambar 2. Pembuatan Kumbung Jamur

b. Pembuatan rak penyimpanan baglog dilakukan bersama mitra dan masyarakat setempat.

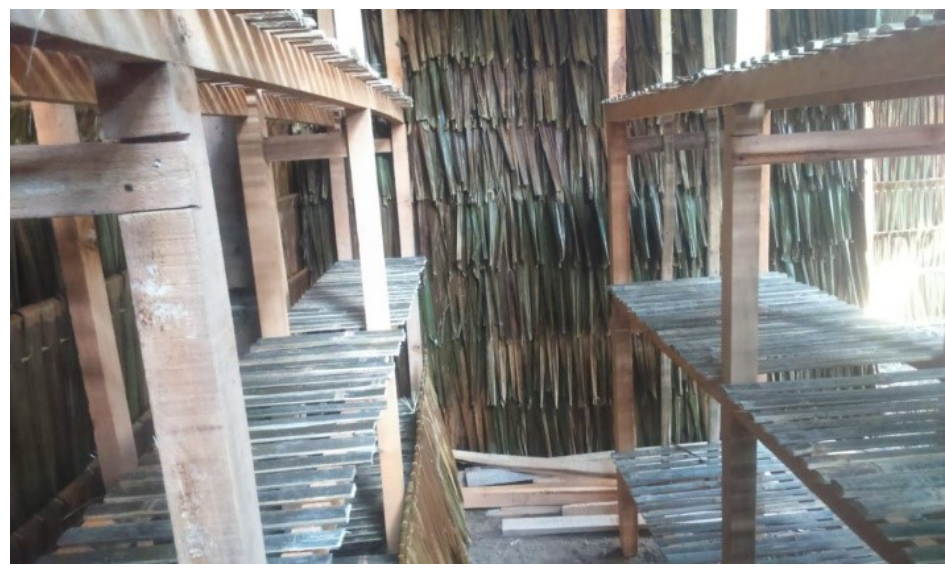

Gambar 3. Pembuatan Rak Penyimpanan Baglog 
c. Pengadaan bahan dan alat untuk pengisian baglog oleh tiem pelaksana PKM dan menyediakan baglog yang sudah disterilkan.

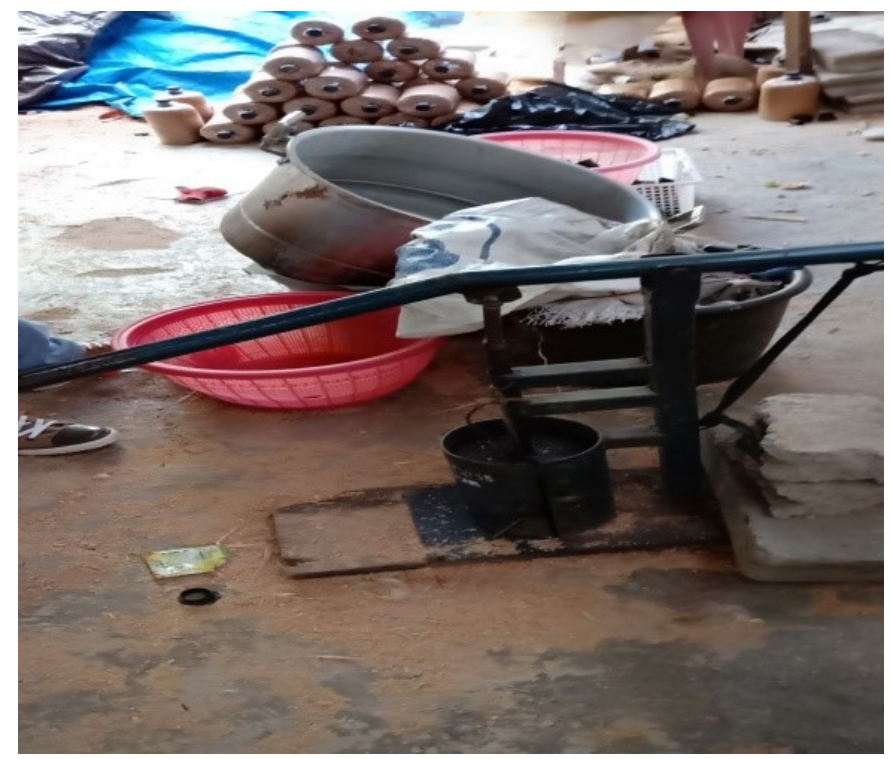

Gambar 4. Bahan dan Alat

3. Penyuluhan dan pelatihan budidaya jamur tiram

Kegiatan ini dilakukan untuk memperkenalkan dan memberikan pengetahuan kepada masyarakat tentang manfaat dan gizi jamur tiram, teknik budidaya jamur tiram dengan berinovasi menggunakan limbah sagu sebagai media jamur tiram. Pelatihan yang diberikan yaitu, desain kumbung jamur, pengolahan media tanam (baglog), pembibitan jamur, pemeliharaan, tata cara panen.

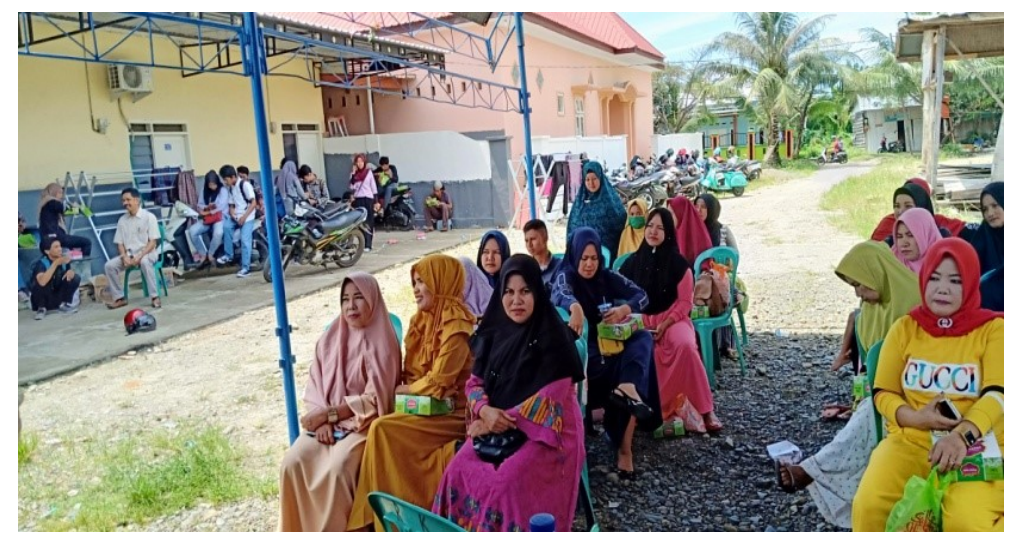

Gambar 5. Kegiatan Pelatihan

4. Pelatihan teknologi hasil dan kewirausahaan

Permasalan mitra yang ada di daerah Kecamatan Pekkajoang yaitu kurangnya pengetahuan pengolahan hasil jamur tiram menjadi berbagai produk olahan yang dapat dijual dan pengetahuan cara berwirausaha serta sistem-sistem pemasaran. Sehingga dengan adanya solusi dari tiem PKM, yaitu, mengadakan pelatihan teknologi hasil jamur dan pelatihan kewirausahaan sehingga menghasilkan produk naget jamur dan keripik jamur tiram. 


\section{SIMPULAN}

Kegiatan yang telah dilakukan dapat ditarik kesimpulan bahwa kegiatan pengabdian masyarakat yang dilakukan dapat menambah pengetahuan warga tentang memanfaatkan limbah sagu menjadi media tumbuh jamur tiram dan pengetahuan teknologi budidaya jamur tiram, pengolahan hasil sampai cara pemasarannya.

\section{UCAPAN TERIMA KASIH}

Ucapan terima kasih kepada Kemenristek Dikti untuk pendanaan kegiatan pengabdian masyarakat ini melalui Program Kemitraan Masyarakat (PKM) Tahun Anggaran 2019.

\section{DAFTAR PUSTAKA}

Asegab. 2011. Bisnis Pembibitan Jamur Tiram, Jamur Merang dan Jamur Kuping. Bogor: Agromedia Pustaka.

BPS Lutra, 2017. Luwu Utara 2017 .https://luwuutara.bps.go.id/diunduh tanggal

Flach, M. 1997. Sago Palm, Metroxylon sagoRottb. IPGRI, Rome, Italy,76p

Piryadi, T. U. 2013. Bisnis Jamur Tiram. Jakarta: Agromedia Pustaka.

Sumarmi. 2006. Botani dan Tinjauan Gizi Jamur Tiram Putih. Jurnal Inovasi Pertanian. 4(2): 124-130.

Susanto, A.N. 2006. Potensi dan Perhitungan Luas Lahan Sagu untuk Perencanaan Ketahanan Pangan Spesifik Lokasi di Provinsi Maluku. Prosiding Lokakarya Sagu dalam Revitalisasi Pertanian Maluku, Ambon

Sangadji, I., Parakkasi, A., Wiryawan, K. G., \& Haryanto, B. (2008). Perubahan Nilai Nutrisi Ampas Sagu Selam pada Fase Pertumbuhan Jamur Tiram Putih (Pleurotus ostreatus) yang Berbeda. Jurnal Ilmu Ternak, 8(1). 